\title{
The Implementation of Bela Negara Value in Citizenship Education in the Efforts to Prevent Radicalism
}

\author{
Surryanto D. Waluyo ${ }^{1 *}$, F. G. Cempaka Timur ${ }^{2}$ \\ 1. Indonesian Defense University, IPSC Sentul Bogor, West Java, Indonesia \\ 2. Indonesian Defense University, IPSC Sentul Bogor, West Java, Indonesia
}

\begin{abstract}
Having a perspective and understanding of radicalism alone is not enough to make someone involved into terrorism. However, the radicalism that leads to the acts of terrorism must be prevented early on by every country either through optimizing the country's defense, or the ability of its citizen as a person and also as group, as well. Various efforts to spread the seeds of radicalism under the guise of religion until this day are still life in colleges. This research use qualitative method with descriptive analytics approach, and collected relevant data through study of literatures. The systematic implementation of the bela negara program in numerous educational institutions including in universities will be assessed if it is effective in stemming radical ideologies that continue to threaten the existence of the National Security.
\end{abstract}

Keywords: Radicalism, Terrorism, Bela Negara, College, and National Security

DOI: $10.7176 /$ RHSS/10-18-10

Publication date:September $30^{\text {th }} 2020$

\section{Introduction}

The development of the current strategic environment also influences the increasingly complex and multidimensional patterns and forms of threats, both in the form of military and non-military threats. The threat faced by the Indonesia state sovereignty today cannot be separated from the influence of the strategic environment development with the rise of vertical and horizontal conflicts within political, economic, socio-cultural and security dimensions. The various influences and negative impacts of the strategic environment development accompanied by changing perceptions and the nature of threats to the existence and sovereignty of the nation, of course, must be scrutinized and addressed by the Indonesian nation seriously.

One type of threat that is still of concern at the national, regional and global scales is radicalism which can then motivate the emergence of terrorism. Terrorism cases, for example, the early detection efforts of terrorism in Indonesia, according to the author, still need to be improved, given that there are still many acts of terror in Indonesia. Based on data from the Global Terrorism Index, Indonesia ranks 35th out of 138 countries affected by terrorism (Institute for Economics and Peace, 2019). Terrorism is a very dangerous crime and is included in the category of extraordinary crime, so it requires serious handling and the involvement of all parties in overcoming this threat.

Globally, the concentration on the root causes of radicalism has been in focus since 2004/2005, especially after the attack on the WTC twin towers in the United States, which was known as the September 11, 2001 incident. Starting from this incident, politicians have gathered various hypotheses on the causes of radicalism that leads to terrorism. Academic researchers in The Routledge Handbook of Terrorism Research identify more than 50 different suspected causes of radicalism, including:

a) Terrorism is rooted on political discontent.

b) A culture of alienation and humiliation can act as a kind of growth medium in which the radicalization process begins and extremism comes on and turn the dynamics of development off.

c) Individual or collective interest to avenge a grudge against the acts of repression might reasonably be the motive for the terrorists' activities.

d) Failure in mobilizing popular support for a radical political program can trigger a decision to use terrorism as an engineered violent confrontation against the authorities.

e) Terrorism options represents the result of a learning process from the experience itself and the others experience. (Schmid, 2011)

Based on the list of causes of radicalism, as mentioned above, a red thread can be drawn that the emergence of the movement of terrorism in a country caused by dissatisfaction with some groups of society in the political aspects. A sense of dissatisfaction is then encourages the formation radical groups that then leads to terrorism, with the purpose of confronting the government. In general, radicalism originates from ideological movements with 
specific motives. All ideological movements was mutually compete gins tech other, however within specified time some of them also build tactical relationships. Similarly, the number of ideological movements were seeded for several decades. Furthermore as the politics liberalization who held post-reform period, all ideological movement find their rides and momentum to grow and develop themselves, including the ideologies which has been buried, like communism. The great ideological politics typology and its variants have grown since the reformation period that are actually became the orientation of various political movements groups of in Indonesia during the reformation period up to now. (Schmid, 2011)

The target of the radical movement groups is the high school student, academics, and limited community. The spread pattern is divided into the several stages, namely the first, on the high school students, the spread through structured and systematic activities that include all the aspects that related to the study, the pattern of development of the movement tend to be exclusive, in fact there are very closed, it is not uncommon to often face minor clashes with the community. Second, the spread pattern in the community of academics is done through the formation of opinion in the mass media and extra parliamentary actions because indeed it directly confronts with the State vis a vis struggle. If the first pattern pursued by networks of social politics movements are derived from the secular values, the second pattern have become the prime choice of social politics movements are derived from the religion values, especially Islam. Third, the last pattern, namely that took place in the middle of society and generally more massive than the first pattern. (Sahid Ali, 2018)

\section{Conceptual Framework}

\subsection{The Concept of Bela negara}

Bela negara is a concept that is formed and regulated by laws regarding patriotism and nationalism of its citizens with the aim of maintaining the existence of the country. Nationalism is an important aspect and needs to be built in the life of the nation and state. According to Hans Kohn in his Nationalism Theory:

"Nationalities are the products of the living forces of history, and there for fluctuating and never rigid."

From the definition above, it can be understood that nationalism is a product of historical life and because of that it is fluctuating and never static. This implies that the past history of a nation has always been fluctuating, therefore it must be studied, so that the younger generation understands and comprehends the history of their nation, especially the history of struggle, because from here nationalism is born as a product of the historical life of a nation. Furthermore, Kohn explained that Nationalism is a feeling, thought, and opinion where the highest loyalty of a person (individual) is addressed to the nation state. (Kohn, 1984)

This sense of nationalism will then be manifested in an attitude of love for the country, patriotism and willingness to sacrifice for the nation and state which is the ultimate goal of bela negara efforts. As quoted from the National Resilience Council, bela negara efforts can be carried out both physically and non-physically. Physically, bela negara can be defined as a defense effort in the face of physical attacks or what is called as aggression from other countries that threatens the country's existence. Meanwhile, what is meant by bela negara through non-physical efforts is an active role in advancing the nation and state through education, morals, social, or the welfare of the people. (Setjen Wantannas, 2018)

By law, bela negara in Indonesia is stated in the state constitution, namely the 1945 Constitution (UUD) Article 27 paragraph (3), that every citizen has the right and obligation to participate in efforts to defending the state. This article is also strengthened by Article 30 paragraph (1) of the 1945 Constitution which states that every citizen has the right and duty to participate in the defense and security of the state. The two articles show that bela negara efforts are not separate from the citizens themselves, because it is an obligation as regulated in the constitution. Soepandji and Farid argued that the bela negara efforts as meant in the 1945 Constitution could be carried out through: (Soepandji and Farid, 2018)

a) Citizenship education ;

b) Compulsory basic military training;

c) Mandatory or voluntary service as Indonesia national army soldier; and

d) Service in accordance with the profession

The description of the bela negara efforts as stipulated in the 1945 Constitution also has relevance to the Social Contract Theory of John Locke, a British philosopher who is considered to be an intellectual giant who contributed to state documents in the history of British nationality: 
"...the man was an intellectual titan, one whose thoughts and ideas can be found throughout our country's earliest political documents, including and especially the Declaration of Independence."

(John Locke Foundation, no date)

In explaining his idea of state formation, John Locke also agreed with his two predecessors, Thomas Hobbes and JJ Rosseau that the basis of the state being formed was due to the Social Contract. The duty of the state in the social contract is to protect and defend citizens' property rights. A new government can be run on the basis of the consent of the community and not the sacred right of the power holders. The opportunity and authority of citizens are given the widest possible opportunity to be able to reduce or withdraw the authority given to their representatives in the government because they have committed a lot of fraud in carrying out their duties. (John Locke Foundation, no date)

\subsection{Radicalism Transformation into Terrorism}

Donatella Della Porta and Gary La Free (2011), put forward several definitions of radicalism and radicalization, namely Radicalization appears to emphasize interactive (movement/state) and processual (gradual escalation) dynamics in the formation of violent groups, often clandestine (Kohn, 1984 in Pratimun, 2016). In this approach, radicalization refers to the actual use of force, with an escalation in terms of form and intensity. Radicalization can be more profitably analyzed as a process of interaction between violent groups and their environment, or the effects of interactions between mutually hostile actors. Functionally, political radicalization increases preparation for and commitment to conflict between groups. Descriptively, radicalization means a change in beliefs, feelings, and behavior in a direction that increasingly justifies inter-group violence and demands sacrifices in defending the group.

Radicalism is the embryo of terrorism. Radicalism is an attitude that crave a change in total and revolutionary by distorting the existing values drastically through violence and extreme actions. There are several characteristics that can be recognized as an attitude of radicalism: (1) intolerance (not wanting to respect the opinions and beliefs of others); (2) fanatical (always feels right for himself; thinks others are wrong); (3) exclusive (differentiating oneself from Muslims in general); and (4) revolutionary (tends to use violent means to achieve goals). (BNPT, 2015)

Schaefer stated, when political communication channels experience this blockage, terrorist attacks occur (Sumarlan, 2016). Terrorism has also been identified as being linked to civilization, when intercourse collides with values, culture, politics, economics, and due to other factors. The rate of collision gets stronger, when the part forces itself to feel superior pushing other civilizations. In this context, when religion becomes the spirit of civilization and its doctrine is interpreted in such a way, it will trigger insistence on militancy against all forms of coercion.

The causes of radicalization that can lead to terrorism are not only at the micro level but also at the meso and macro levels (Schmid, 2013):

a) The micro level, namely the individual level, which involves eg. identity problems, integration that fails, feelings of alienation, marginalization, discrimination, relative deprivation, humiliation (directly or by representative), stigmatization and denial, often combined with moral anger and feeling of revenge (representative).

b) The Meso level, namely more spacious radical environment - social environment which supports or even involved - which serves as the point of intersection and the 'the missing link' with a constituency or group of terrorists references were more extensive that harmed and suffered injustice that, in turn, it can radicalize parts of youth groups and lead to the formation of terrorist organizations.

c) The macro level, which is the role of government and society at inside and outside the country, the radicalization of public opinions and political parties, the strained majority - minority relationship, especially when it concerns the diaspora foreigners, and the role of the lack of opportunities of socio-economic for the whole sector of society which leads to unsatisfied mobilization and radicalization, some in them may take the form of terrorism.

From the three levels of analysis above, it is possible to obtain close answers about the socio-psychological causes of radicalization, socialization, terrorism mobilization and the process of individual/group involvement in the related escalation. Most research suggests that there is no single cause other than a mixture of the complex factors that are internal and external attractants and drivers, triggers and propeller that can lead to individual radicalization and even turn large collective groups into radicals and violent extremists. 
The relationship between radicalism and terrorism is a complex one. John Horgan has correctly noted that 'the relationship between radicalization and terrorism is poorly understood' - or every radical becomes a terrorist 'and/or every terrorist has a radical view' (RAND, no date). It is also important to distinguish between terrorism as a political doctrine and terrorism as an act of political violence. Political terrorist crimes are very similar to war crimes in that they both involve, in essence, deliberate attacks on civilians and / or the taking of hostages. However, efforts to define acts of terrorism as 'the peacetime equivalent of war crimes' so far have not received broad state support.

Another factor that motivates a person to join terrorist networks. First, domestic factors, namely domestic conditions such as poverty, injustice or feeling disappointed with the government. Second, the international factor, namely the influence of the global environment which encourages the growth of religious sentiments such as injustice, arrogant foreign policy, and modern imperialism of the superpower country. Third, cultural factors that are closely related to shallow religious understanding and narrow and lexical interpretation of holy books (harfiyah). Radical attitudes and understandings motivated by the various factors above often make a person choose to join terrorist acts and networks (Schmid, 2013). There is also a process of radicalization generally going through the following phases (Christmann, 2012):

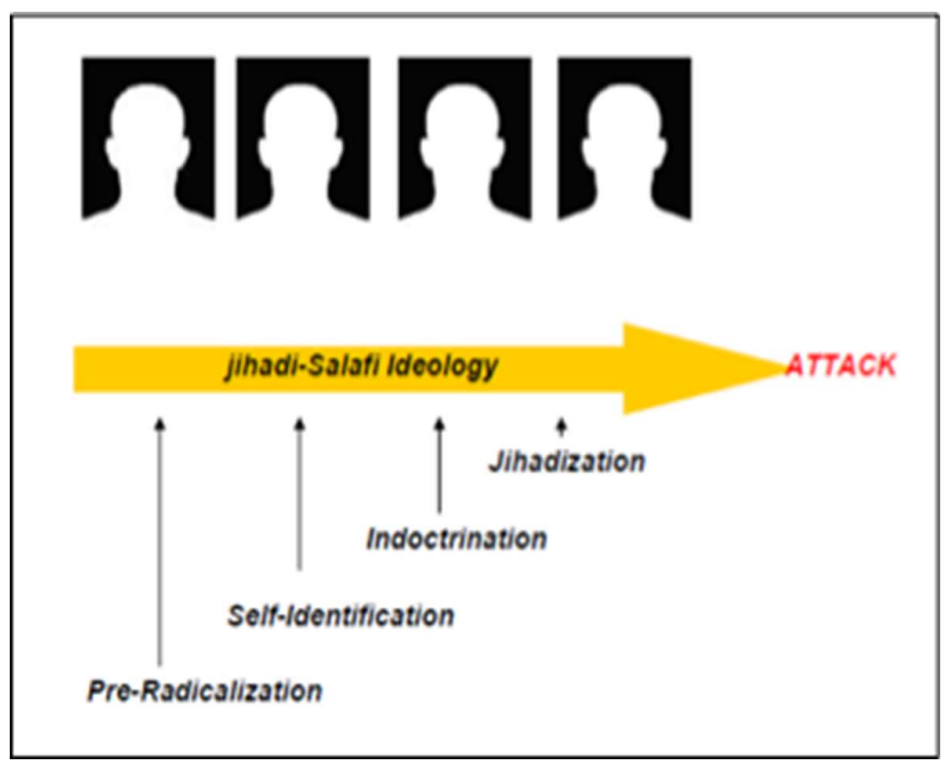

Figure 1. Radicalization Phase

( Source: NYPD (2007). Radicalization in the West: The Homegrown Threat, in Christmann, 2012)

a) Pre-radicalization: the stage early this describes the situation of the life of a person before radicalization and before the presentation and adoption of the Islamic-Salafist Jihad ideology.

b) Self-identification: this stage includes early exploration of the people about the Salafist and gradual gravitation from their previous identity, beginning of a relationship with people who have the same idea and the adoption of this ideology as it belongs to them. "The cognitive opening" provide a catalyst for this, in which the quest of religion is the cognitive opening, or crisis, which shook the foundation of someone's belief and make them accept the view of the new world.

c) Indoctrination: Phase three is seeing someone further strengthen their confidence, and ultimately fully adopted the ideology of Jihad-Salafi. This leads to the belief that conditions and circumstances exist where action that is needed to support and advance the causes of militant Jihad. This phase is usually facilitated and encouraged by the "spiritual demander". The importance of this phase is a relationship with people who think alike to 'deepen' the indoctrination. The role of the group became increasingly formative in encouraging and reinforces the view that hardens.

d) Jihadization: this is the final operational stage in the radicalization process, in which cluster members accept individual assignments to participate in Jihad, "to designate themselves as holy warriors or mujahadin". In the end, seeing the group perform terrorism assault, including the planning, preparation and execution (i.e. leads to Tier 4 - actively violate the law).

There is nothing inevitable about this process, not all who initiate the process progress through all the stages, and they can stop or leave the radicalization process at different points. However, those who made progress were 
considered 'highly likely' to be involved in planning or implementing terrorist acts.

\section{Discussion}

\subsection{Global and Indonesian Terrorism Movement}

In recent decades, the international community has faced the real threat of radicalism and terrorism, namely the emergence of the Islamic State of Iraq and Syria (ISIS) group. ISIS, also known as ISIL (Islamic State of Iraq and the Levant ) is a Sunni jihadi group with a very strong ideology and this group claims to have strong authority over all Muslims (RAND, no date). ISIS remains a radical Islamic terrorist group and is a major transnational terrorist threat to the United States, despite ongoing efforts by the United States and its coalition to reduce the group's presence in Iraq and Syria, attempts to kill thousands of members, and limit global expansion.

ISIS retains the financial and material resources and expertise to launch external attacks, including against United States interests and its senior leaders continue to call for attacks on the United States. The group's global reach is particularly strong, given that there are eight official chapters and more than two dozen networks that regularly carry out terrorist and insurgent operations throughout Africa, Asia, Europe and the Middle East. Despite many setbacks, ISIS maintains a sophisticated and durable media presence within a network that enables it to encourage and enable sympathizers around the world to carry out dozens of attacks in target countries, including the United States.

If it is related to the history of the Indonesian nation, cases of radicalism and similar terrorism have often occurred since the early independence of this country with the efforts to establish an Islamic state in Indonesia. During the Old Order Government, Indonesia faced the threat of rebellion from the Darul Islam/Islamic Army (DI/TII) movement group led by Kahar Muzakar in South Sulawesi, Ibn Hajar's rebellion in South Kalimantan, Kartosuwiryo's rebellion in West Java and Daud Beureueh's rebellion in Aceh. This rebellious action certainly threatens the existence and sovereignty of the state because it is against the Constitution and Pancasila. As stated in the 1945 Constitution Article 1 (1) that Indonesia is a Unitary State in the form of a Republic and it is stated in Precepts 1 and 3 that Indonesia recognizes the diversity of religious beliefs and upholds unity. (Undang-Undang Dasar Negara Republik Indonesia Tahun 1945)

The rebellion case at the beginning of Indonesian independence made Indonesia a fertile ground for the radicalism development. This is a warning for the Indonesian people to respond to the predicted Indonesian citizens who involved in the ISIS movement to return to Indonesia by carrying out terror and radical activities. Therefore, one of the effective ways to ward off these threats is to strengthen all components of civil society that exist in Indonesian society. Starting from political parties, non-governmental organizations, social organizations, religious organizations, and other community organizations to dialogue, exchange information and close ranks to prevent terrorism practices. (Fitriani et al., 2018)

There are two patterns of radicalism spread in Indonesia, namely First, through the NGO (Non-Government Organization). The NGO phenomenon in Indonesia has actually existed since the 1970s. But as the movement of a group of critical vis a vis to the state, only newly evolved since the early decades of the 1990s. NGO or NGOs, to carry out various program activities to get the support of funding from International donor institutions which is the creation of the foreign state or internationally entities not countries. As usual, all these donor agencies in carrying out their mission have certain ideological tendencies, from liberal democratic, social democratic, to the far left. Or, from the economic ideology, ranging from the most right as neoliberalism, until socialism radical. In a relationship of cooperation with the Indonesian NGO, we can record that since first half decade of the 1990s, in addition to increase the amount of international funding entering Indonesia, the programs implemented are also experiencing significant changes. If the previous program were shaped as community development to increase skill society in various fields, on the other hand this decade they have focused on advocacy and development of CSO (Civil Society Organization) whose mission is political. In running the programs mentioned, NGO Indonesia became a sort of agent for the seed ideas of critical toward groups of people; and since this decade they also the target group has risen to a strategic and selective group, such as the journalists, members of the legislature, figures, and among the educated, especially students. Second, through the creation of groups of study or group study like liqo ' or usroh, and or establish informal civil society organizations, such as in the form of jamaah.

As well as the NGO is part of a international movements network which are centered in Western countries, the study group or recitals is also part of the international movements network, which center is in the Middle East. The ideology of the movement which embraced also very diverse, from the apolitical like Jamaat Tabligh, to the politically like Ikhwanul Muslims and HTI (Hizbut Tahrir Indonesia), as well as the radical like Salafi Jihadi. In 
addition to the sources from Islam, new religious movements that comes from Christianity, Hinduism and Buddhism, both the moderate and radical, during the middle of the 1990s was also popping a lot.

\subsection{Citizenship Education and Bela Negara in the Efforts to Prevent Radicalism in Indonesia}

Bela negara is a fortress for the state in saving the continuity of the nation's life. According to the theory of the Social Contract, John Lock has the duty to protect the property rights of the state and its citizens. The implementation of the task of protecting the property rights of the state and its citizens, including defending and protecting the Republic of Indonesia from threats that come from within and outside the country is the right and obligation of every Indonesian citizen. This has been stated in the 1945 Constitution Article 27 paragraph (3) which states that "Every citizen has the right and obligation to participate in efforts to defending the state". Article 30 paragraph (1) and (2), that "Every citizen has the right and duty to participate in the defense and security of the country.

The sense of nationalism, patriotism and love for the country which are the main elements of the spirit of Bela negara are very important, in the midst of the heavy influence and negative impact of the development of this strategic environment. Therefore, the formation of a Bela negara attitude must be carried out as early as possible through a Bela negara program by fostering love for the country, awareness of the nation and state, willingness to sacrifice for the nation and state, to live and practice Pancasila so that they have a mental attitude that is aware of rights and obligations and responsibilities as citizens.

Observing the condition of conflicts emergence followed by violence in the era of globalization and information, if the state structure is not managed intelligently and wisely, it will cause the fading of the spirit of togetherness, harmony frailty, declining solidarity and creating vulnerabilities to national disintegration which will result in decreased self-esteem and national dignity and the Unitary State of the Republic of Indonesia. The transition period of identity crisis among youth is likely to experience what Quintan Wiktorowicz (2005) calls the cognitive opening, a micro-sociological process that brings them closer to acceptance of new, more radical ideas (Beck, 2015). For such reasons, they are very vulnerable to the influence and persistence of violent groups and terrorism. Meanwhile, terrorist groups are aware of the psychological problems of the younger generation. Terrorist groups target those who are always dissatisfied, irritable and frustrated with both social and government conditions. They have also provided what they need in terms of justification, solutions and strategies for achieving change, and a sense of belonging. Terrorist groups also provide an environment, facilities and equipment for teenagers who want courage and launch their violent agenda.

The development of Bela negara awareness in counteracting some of the phenomena above has also not been carried out comprehensively by state administration, including the use or utilization of infrastructure for developing Bela negara awareness initiated by ministries and institutions such as Bela negara education facilities, coordination between ministries and government agencies is required. Because fostering awareness of Bela negara is an inseparable part of national development so that its implementation is not only the responsibility of the Ministry of Defense but also a shared responsibility through ministries/institutions as well as all other components of the nation.

There are three social institutions that are very important to play a role in protecting the younger generation. First; educational institutions, through the role of educational institutions, teachers and curricula in order to strengthen national insight, moderate and tolerant attitudes of the younger generation. Second; family, through the role of parents in instilling love and affection for the younger generation and making the family a unit of consultation and discussion. Third; community: through the role of community leaders in the community in creating a conducive space for the creation of a culture of peace among the younger generation. It takes conscious and well-planned efforts to instill in citizens the foundation and values of Bela negara as follows, namely:

a) Love for the motherland. Bela negara program will emphasize the importance to foster attitudes and behaviors of love of the nation. It is, in accordance with the definition of Bela negara that the attitude and behavior of the citizens of Indonesia who imbued love of the nation based on Pancasila and the 1945 Constitution in guaranteeing the continuity of life of nation and state.

b) The nation and state awareness. Bela negara usually always associated with the military or militarism, as if the obligations and responsibilities for defending the country only lies in the military. In Bela negara program focuses on awareness to defend the country which stresses on one thing that is essential and should be owned by every citizen of Indonesia, as a form of redemption rights and obligations in an effort to defend the country. Bela negara awareness become a basis and also the strength of the nation, in order to maintain the integrity, sovereignty and the survival of life of the nation and state of Indonesia. 
c) Believe in Pancasila as the state ideology. Values are developed in the Bela negara program is to believe in Pancasila as an ideology of the state, one of the strategies to build resilient nation to confront the complexity of the threat. The strategy will actualized when there is an alignment in cross-sectoral organization, as a form of sole responsibility of human resources development to realize the unity and continuity of NKRI. It is hoped that there will be an understanding that fostering Bela negara awareness is an effort to build the character of the nation.

d) Willing to sacrifice for the nation and state of Indonesia. Bela negara program also foster citizens state to have a willing to sacrifice spirit for the nation and the state, which is willing to sacrifice time, energy and thought to the progress of the nation and the state, ready to sacrifice life and soul for the sake of defending the nation and the state from various threats, to participate actively in society development, the nation and the state, keen to help fellow citizens of countries in experiencing difficulties, convinced and believe that sacrifice for the nation and the state is not in vain.

e) Have the initial Bela negara ability. Psychically, having emotional, spiritual intelligence as well as intellectual, always maintaining the soul and his body as well as having the properties of discipline, tenacious, work hard and resiliency. Meanwhile, physically, namely having a good health condition and physical skills. The fifth base value of the Bela negara should be seen as virtues of life that must be internalized by the citizens of the state on all layers. (Tippe, 2017)

If you review the spread pattern of radicalism and terrorism in Indonesia, one of the prevention efforts that plays an important role is through Citizenship Education in schools and colleges. This is reinforced by Law No. 20 of 2003 concerning the National Education System Article 37 Paragraph (1) letter b, which states that the primary and secondary education curriculum is obliged to contain citizenship education. Likewise, in paragraph (2) letter $\mathrm{b}$ it is stated that the higher education curriculum is obliged to contain citizenship education. It is said that the scope of citizenship education as referred to in the law is education which includes Pancasila, the 1945 Constitution of the Republic of Indonesia, the Unitary State of the Republic of Indonesia and Bhinneka Tunggal Ika to form students to become citizens who have a sense of nationality and love the country. Citizenship education is intended to shape students into human beings who have a sense of nationality and love for the country as mentioned in Law No. 20 of 2003, Elucidation of Article 37. (Undang-Undang Republik Indonesia Nomor 20 Tahun 2003 Tentang Sistem Pendidikan Nasional)

In Citizenship Education learning, first, students will gain an understanding and sense of belonging as Indonesia Citizen can be achieved by studying national history, law, social and national culture. Second, students get an understanding the efforts to build a sense of nationality. Third, knowing the manifestations and contributions that can be given from the love of the country. Fourth, identify the efforts to become smart and good citizens by understanding the rights and obligations of citizens. Fifth, understanding the importance of Bela negara and how to implement these efforts into citizen behavior.

Thus, Citizenship Education in education programs plays a very important role in efforts to prevent the spread of radicalism and terrorism in Indonesia. Because, through this education, basic cultivation of nationalism and love for the country can be given to students who are categorized as vulnerable groups to become targets of the radicalism spread. As mentioned by Soepandji and Farid in the previous section, Bela negara efforts can be realized through Citizenship Education and professionalism. It is hoped that through this education, in the future students can understand the indicators of realizing Bela negara efforts in order to maintain the existence of the nation and also the state, and understand the dangers of the threat of radicalism and terrorism that are contrary to the constitution and values contained in Pancasila.

\section{Conclusion}

From the description above regarding Bela negara in Citizenship Education as an effort to overcome and prevent the spread of radicalism and terrorism in Indonesia, it can be concluded as follows:

a) There are several things that can be done by the younger generation, in order to counteract the influence of radical ideologies and teachings, namely: (1) instill a spirit of nationalism and love for the Republic of Indonesia; (2) enrich moderate, open and tolerant religious insights; (3) fortify self-confidence by always being vigilant against provocation, incitement and patterns of terrorist recruitment both in the community and cyberspace; (4) building networks with peaceful communities both offline and online to increase insight and knowledge; and (5) join in peace.id as community media in order to flood the virtual world with messages of peace and love for the Republic of Indonesia.

b) The vulnerability of the young generation in facing changes in the global environment makes the younger 
generation, especially students as targets and easy entry points for radical ideologies, so that it needs to be strengthened by understanding the social contract as citizens through bela negara. Bela negara that is the determination, attitude and actions of state citizens that is organized, comprehensive, integrated and continued that based on the love of the nation, the awareness of national and state of Indonesia as well as the confidence to be the sacred Pancasila as an ideology of the country and willingness to sacrifice in order to negate any threat either from the outside as well as from within the country that harm the independence and sovereignty of the country, the unity and the unity of the nation, the integrity of the territory and national jurisdiction, as well as the values of Pancasila and the Act of 1945.

c) The nationwide strategic environment development, giving the impact in the various areas of the life of the nation and also affects the degradation in the implementation of Pancasila as an ideology of the state. It is can be seen from the various events of violence, unrest and conflict set in the back of ethnic, religious, racial and inter- group that carried out by groups of radicals. The phenomenon that causes the values to bela negara into decline. Therefore, the values to Bela negara become owned absolutely by the citizens of Indonesia with fostering love of the people of Indonesia to the nation, awareness of nation and state, willingness to sacrifice for the sake of the nation and the state, to live and practice Pancasila so they have the attitude of mental to realize the rights and obligations and responsibilities as citizens of the state.

\section{References}

Beck, C. J. (2015) Radicals, Revolutionaries, and Terrorists. UK: Polity Press.

BNPT (2015) Strategi Menghadapi Paham Radikalisme Terorisme - ISIS. Jakarta: BNPT.

Christmann, K. (2012) Preventing Religious Radicalisation and Violent Extremism: A Systematic Review of the Research Evidence. Youth Justice Board. Available at: https://pure.hud.ac.uk/en/publications/preventing-religious-radicalisation-andviolent-extremism-a-syste (Accessed: 1 August 2020).

Fitriani et al. (2018) The Current State of Terrorism in Indonesia: Vulnerable Groups, Networks, and Responses. Jakarta: Centre for Strategic and International Studies.

Institute for Economics and Peace (2019) Global Terrorism Index 2019: Measuring The Impact of Terrorism. Sydney. Available at: http://visionofhumanity.org/reports.

John Locke Foundation (no date) Who is John Locke?, John Locke Foundation. Available at: https://www.johnlocke.org/aboutjohn-locke/who-is-john-locke/ (Accessed: 8 August 2020).

Kohn, H. (1984) Nasionalisme arti dan sejarahnya / Hans Kohns; diterjemahkan Sumantri Martodipuro. Edited by S. Martodipuro. Jakarta: Erlangga.

Pratimun (2016) Program Bela Negara Guna Menyikapi Kebhinekaan Bangsa Indonesia. Bandung: Seskoad.

RAND (no date) The Islamic State (Terrorist Organization), Rand Corporation. Available at: https://www.rand.org/topics/theislamic-state-terrorist-organization.html (Accessed: 11 August 2020).

Republik Indonesia (1945) Undang-Undang Dasar Negara Republik Indonesia Tahun 1945. Jakarta: Republik Indonesia.

Republik Indonesia (2003) Undang-Undang Republik Indonesia Nomor 20 Tahun 2003 tentang Sistem Pendidikan Nasional. Jakarta: Republik Indonesia.

Schmid, A. (2013) 'Radicalisation, De-Radicalisation, Counter-Radicalisation: A Conceptual Discussion and Literature Review', The International Centre for Counter-Terrorism - The Hague. The International Centre for Counter-Terrorism (ICCT), 4(2). doi: 10.19165/2013.1.02.

Schmid, A. P. (ed.) (2011) The Routledge Handbook of Terrorism Research. Routledge. Available at: https://www.routledge.com/The-Routledge-Handbook-of-Terrorism-Research/Schmid/p/book/9780415520997.

Setjen Wantannas (2018) Bela Negara: Pengertian, Unsur, Fungsi, Tujuan Dan Manfaat Bela Negara, Dewan Ketahanan Nasional. Available at: https://www.wantannas.go.id/2018/10/19/bela-negara-pengertian-unsur-fungsi-tujuan-dan-manfaatbela-negara/ (Accessed: 1 August 2020).

Soepandji, K. W. and Farid, M. (2018) 'Konsep Bela Negara dalam Perspektif Ketahanan Nasional', Jurnal Hukum \& Pembangunan. Jurnal Hukum dan Pembangunan, 48(3), p. 436. doi: 10.21143/jhp.vol48.no3.1741.

Sumarlan, S. (2016) Implementation of Deradicalization Policy For Terrorism Prisoners: An Indonesian Case. Indonesian Defense University.

Tippe, S. (2017) Redesain Bela Negara dalam Sistem Pendidikan Nasional. Jakarta: Yayasan Pustaka Obor Indonesia. 